IRSH 6I (2016), pp. 95-I I 6 doi:10.10I7/S00208590I600003 I

(C) 2016 Internationaal Instituut voor Sociale Geschiedenis

\title{
E.P. Thompson in South Africa: The Practice and Politics of Social History in an Era of Revolt and Transition, I976-20 I 2
}

\author{
JONATHAN HYSLOP \\ Sociology Department, Colgate University \\ I3 Oak Drive, Hamilton, NY 13346, USA
}

E-mail: jhyslop@colgate.edu

\begin{abstract}
The work of E.P. Thompson has had an enormous impact on the writing of history in South Africa since the I970s. This article traces the rise of this historiographical trend, focusing especially on the History Workshop at Wits University (Johannesburg). It outlines how a South African version of Thompsonian historical practice was theorized, and sketches some of the ways in which Thompson's ideas were utilized by South African historians. The article shows how the History Workshop attempted to popularize their research, and examines the political projects behind these activities. Finally, the article suggests that although the influence of Thompson-style South African social historians has declined, their work has had a lasting impact on the country's literary culture, well beyond the academy.
\end{abstract}

In 2009, one of South Africa's most prominent young journalists, Jacob Dlamini, published a book that was to prove highly controversial. Entitled Native Nostalgia, it explored why, despite the grisly nature of the apartheid system, at least some black South Africans, including the author himself, reflected on township life in those times with feelings of affection. ${ }^{\text {I }}$ Dlamini's aim was not to minimize the horrors of apartheid, or to deny what was positive about the present. Rather, it was to make a point about versions of history. An official narrative was developing, portraying the entire modern history of South Africa as a story of how the ANC had led the process of the liberation, from its exile headquarters in Lusaka, Zambia, showing a unified African people the way to the future. What Dlamini was seeking to say was that this was an altogether simplistic framework into which to crowd the complexity of black experience. For him, it did not

I. Jacob Dlamini, Native Nostalgia (Johannesburg, 2009). 
recognize the creative social spaces that people in the townships had been able to carve out for themselves in the most adverse of circumstances, it did not acknowledge the conflicts, divided loyalties and betrayals that had existed within the struggle, and it did not face the reality of the problems of the present, which could not always be reduced to the legacies of apartheid.

Dlamini invoked a perhaps unexpected authority for his highly controversial argument. On page I 3 of the book, he wrote:

[...] the freedom of black South Africans did not come courtesy of a liberation movement. There were bonds of reciprocity and mutual obligation, social capital that made it possible for millions to imagine a world without apartheid. To apply what E.P. Thompson said of the English working class, black South Africans were present at their own making as citizens. Freedom was not sent to them in a gift box from Lusaka. ${ }^{2}$

This statement immediately provokes a number of questions. Why would a young South African writer, in the year 2009, choose to refer to The Making of the English Working Class? Why would he find some of Thompson's central ideas useful? Why should he write in a tone that might suggest that his intended audience, clearly an educated but not an academic one, might reasonably be expected to know who E.P. Thompson was?

In this article, I will provide an account of the "career" of E.P. Thompson in South Africa. Thompson never visited the country, although, as a couple of references to apartheid in The Making suggest, he was well aware of the importance of its political struggles. ${ }^{3}$ Nevertheless Thompson's work had an enormous impact on the writing of history in South Africa, beginning in the I970s, reaching its height in the I980s and early I990s, and extending into the present. South African scholars have, amongst themselves, diametrically opposed views on whether this influence was a benign one or not, but that it existed seems incontestable. A Thompsonian brand of history also gave an intellectual impetus to remarkable efforts in the popularization of historical research over the last four decades. This body of Thompsoninfluenced South African work holds much that is of value, and it has played a small but noticeable role in shaping contemporary South African literary culture and memorialization practices beyond the academy.

The article focuses particularly on the key group in the development of a Thompsonian style of social history in South Africa, the Johannesburg History Workshop. It is important to say at the outset, though, that it is not intended as a comprehensive account of that group, less still of social history in South Africa as a whole. Instead, the article seeks to trace only the most direct connections between Thompson's oeuvre and the work

2. Dlamini, Native Nostalgia, p. I3.

3. E.P. Thompson, The Making of the English Working Class (New York, I966 [1963]) pp. 177, I 98. 
of South African historians. Nor do I seek to make any macro-sociological generalizations about the relationship between "northern" and "southern" social theory, the sociology of academic knowledge or the like. Rather, similarly to the other pieces in this special edition, the article shows how, at a particular moment, Thompson's ideas were taken up by scholars in a very different setting from that of England. It attempts to explain why his work appealed to scholars in South Africa, and to trace how they applied, and perhaps "creatively misread" his writings in their own context.

The History Workshop came together in the late seventies at the University of the Witwatersrand, Johannesburg, popularly known as Wits (pronounced "Vits"). ${ }^{4}$ A few individuals interested in labour history, including, notably, the historian Phil Bonner and the sociologist Eddie Webster, organized the first conference on labour history at the University in I 976. Shortly thereafter, Belinda Bozzoli and Charles van Onselen came to work at Wits after studying and working abroad.' Bozzoli and Van Onselen were rapidly to emerge as, respectively, the leading theorist of a South African adaptation of the Thompsonian style of social history, and as its most creative practitioner. In 1977, these four and a number of others formed a group known as the History Workshop, which held its first academic conference in early 1978. From then until the present, the Workshop has been the focus not just of a series of important academic conferences, but also of a huge range of initiatives in popular education and heritage. Bozzoli would lead the Workshop until i987, when Bonner took over and guided it through the next two and a half decades. The Workshop continues to flourish today, under the leadership of Noor Nieftagodien, although most of the early participants have dropped away at one point or another.

Who were the History Workshop? Essentially, it was always a small committee, based at Wits. It was a remarkably interdisciplinary group, which was a source of its intellectual strengths. There was a strong British academic connection - and it is here that the vector of Thompson's influence on them is to be sought. More than half of the key individuals in the early years of the Workshop had degrees from British universities. The cultural links between South African and British institutions formed during the days of Empire meant that the United Kingdom was the primary

4. Declaration of interest: The author was an active member of the committee of Wits History Workshop from 1987 to 2010.

5. Belinda Bozzoli, born South Africa, daughter of G. Bozzoli, engineer, scientist and educationist. Educated University of the Witwatersrand and University of Sussex. Former Deputy ViceChancellor, University of the Witwatersand. Currently Member of the South African Parliament for the Democratic Alliance. Charles van Onselen, born South Africa, son of L. van Onselen, police officer and writer. Educated Rhodes University, Grahamstown, University of the Witwatersrand, and Oxford University. Currently Research Professor at the University of Pretoria. 
overseas destination for South African graduate students - relatively few went to the US or continental Europe. ${ }^{6}$ And there was still something of a flow of British graduates to jobs in South African universities. Also, intellectual political exiles tended to make for England.

Three UK-based intellectual developments had a great impact on the Workshop. First, they were influenced by the new British Africanist scholarship that was coming out of the School of Oriental and African Studies at London (SOAS) and elsewhere, focusing on recovering African agency. Especially important here was the work and support of the SOASbased South African Shula Marks. Second, almost all of the young South Africans who studied history or social sciences in Britain during the I970s were to some extent exposed to the wide range of ideas generated by the then current efflorescence of Marxist scholarship. ${ }^{7}$ Third, very importantly, Bozzoli and Van Onselen participated in the meetings of the History Workshop at Ruskin College in Oxford, which gave them a particularly strong link to the British social history tradition. ${ }^{8}$

\section{THE HISTORY WORKSHOP IN SOUTH AFRICAN CONTEXT}

In order to understand why the writings of E.P. Thompson found resonance in the South Africa of the I970s and I980s, the reader will need to know something of the political context of South African intellectual history and of the institutional shape of South African universities in that period. The late ig6os saw the apparent triumph of a completely racialized social order. The main oppositional movements, the African National

6. For the "deep" background of the connection between universities in the British settler colonies and the United Kingdom, see Tamson Pietsch, Empire of Scholars: Universities, Networks and the British Academic world I850-1939 (Manchester, 2013).

7. There is also another dimension to the British connection. Of the ten 198 I History Workshop committee members, seven were South African born, but three had British family backgrounds, with a trajectory through late colonial Africa: Tom Lodge had spent part of his early childhood in Nigeria, where his father had worked for the British Council; Bonner had grown up in Kenya; both had taken jobs at Wits after doing graduate work in South Africa. David Webster's father had worked on the Zambian copper mines, but David had been educated in South Africa and remained there.

8. The UK History Workshop was initiated in 1967 and its influence peaked during the 1970s. It was led by a group of social historians including Raphael Samuel, Anna Davin, Tim Mason, and Sally Alexander. It gave rise to the influential History Workshop Journal. A significant feature of its gatherings at Ruskin (an independent labour-orientated college in Oxford) and elsewhere was an attempt to bridge the gap between historians and activists, something that clearly served as a model for the South Africans. It should be noted, though, that while the British History Workshop was crucially shaped by Thompson's work, there were some intellectual divergences and tensions between its leaders and Thompson. An extensive collection of UK History Workshop material is available online http://www.historyworkshop.org.uk/the-history-workshoparchives-an-introduction/; last accessed 9 December 2015 . For a participant's accounts, see Anna Davin, "The Only Problem was Time”, History Workshop Journal, 50 (2000), pp. 239-245. 
Congress (ANC), its ally, the South African Communist Party (SACP), and the Pan Africanist Congress (PAC), were dismantled by the state, their leaders in prison, under house arrest, or in exile. But there were signs at the beginning of the seventies of renewed resistance from new forces. The Black Consciousness Movement emerged amongst students, and there were demonstrations and signs of radicalization amongst small numbers of white students. A new movement of independent black trade unions started up, and in 1973 there was a spectacular strike wave. In 1976, a mass school pupil revolt began in Soweto and spread across the country, while the state responded with massive violence. New independent black trade unions became a significant force and in 1979 the militant Federation of South African Trade Unions (FOSATU) was formed. Small community activist groups started to spring up. These movements owed very little to the exile organizations, which were obsessively focused on their (not very successful) strategy of guerilla warfare. The ANC and the Communist Party were, in the late I970s, actively hostile to the new trade unions, which they saw as a diversion from their militarist approach, and quite unfairly labelled as collaborationist. But they slowly came to recognize the potential of above-ground organization. By the start of the I980s the ANC and SACP were successfully rebuilding their internal networks, and began to hegemonize the new internal movements. This culminated in the foundation of the United Democratic Front (UDF) in 1983, an umbrella group that was broadly aligned with ANC ideology, but which placed somewhat greater emphasis on questions of mass participation and of non-racial ideology than the ANC had historically done. ${ }^{9}$

South African social historians of the time were involved in, or supported, organizations across the whole of this political spectrum. A few individuals were drawn into the underground ANC. Early History Workshop member David Webster clandestinely joined the movement; tragically, he was assassinated by a government hit squad. ${ }^{10}$ But generally, the scholars who were attracted to a Thompsonian style of social history were sympathetic to the emerging black trade unions and community organizations, and felt a mix of wariness and sympathy towards the ANC. In particular, they often disagreed profoundly with the ANC's antagonistic view of the new unions. Amongst the early History Workshop group, Phil Bonner and Eddie Webster were deeply involved in the FOSATU labour movement, while Luli Callinicos, who in earlier life had been a member of the ANC-aligned Congress of Democrats, became engaged in union education. Many of the graduate students drawn to the Workshop participated in student, community and political campaigns.

9. Jeremy Seekings, The UDF: A History of the United Democratic Front in South Africa, 1983 to I99I (Cape Town, 2000).

Iо. Deborah James, "David Webster: An activist anthropologist twenty years on", African Studies, 68 (2009), pp. 287-297. 
Some of the initial Workshop group - especially Van Onselen - were very sceptical of the organized left in general. The activists and the sceptics alike, though, tended to view the SA Communist Party in ways that resonated with Thompson's critique of Stalinism. For all its undoubted heroism, the SACP remained ideologically one of the most unreconstructed Stalinist parties in the world. It was proud of its support for the Soviet invasions of Hungary and Czechoslovakia, and in the I970s and in the I970s added its unwavering backing for the murderous Mengistu regime in Ethiopia and the USSR's intervention in Afghanistan. It also treated the Soviet version of "historical and dialectical materialism" as received wisdom, adding only a slight nationalist gloss. ${ }^{\text {II }}$ Thompson's attempts to re-examine the basic assumptions of his early, Communist Party political and intellectual life were likely to appeal to those who were not convinced by the SACP's line (but, in varying degrees, might have once sympathized with it or were still moving in its spheres of influence). The social historians were almost all critical of Stalinism's lingering influence on the South African oppositional movements. To this extent, their work can be considered part of the global "New Left" in which Thompson's thought played such a vital role. ${ }^{\mathrm{I} 2}$

Thus, new movements stimulated intellectuals' interest in better understanding working class history and culture. And the participants in these movements - students, trade unionists, community activists - were a potential audience for their work. At the same time, Thompson's approach to social history provided a number of young South African academics with a template for a new kind of engaged scholarship, not only in general but also vis-à-vis other Marxism-inspired intellectual perspectives. At least a part of the success of Thompson's work in the mid to late I970s came because a group of intellectuals reacted against the influence on radical South African thought of Thompson's great antagonist, Louis Althusser, and other Francophone Marxist structuralists. In the I950s and I960s, anti-apartheid scholarship had been dominated by liberals. From the early i 970 s they faced a Marxist challenge. This took a form in which Althusserian ideas were central. A South African Communist exile in Britain, Harold Wolpe, published a series of articles that explained apartheid as a system based on the exploitation of ultra-cheap migrant labour, made possible by the way in which family subsistence production in the rural areas subsidized migrants' wages. Basing himself on Althusser and on the anthropology of Claude Meillasoux, Wolpe delivered an analysis of the "articulation" of modes of production underpinning the South African

I I. Stephen Ellis and Tshepo Sechaba, Comrades Against Apartheid: The ANC and the South African Communist Party in Exile (Oxford, 1992); Stephen Ellis, External Mission: The ANC in Exile, $1960-1990$ (London, 2012).

I 2. Daniel Geary, “'Becoming International Again': C. Wright Mills and the Emergence of a Global New Left”, Journal of American History, 95 (2008), pp. 710-736. 
social order. ${ }^{\mathrm{I}}$ The ideas of some of the South African intellectual left over the next couple of decades were substantially shaped by Wolpe. Moreover, the influence of Althusser was reinforced via that of one of his followers, Nicos Poulantzas. In the mid-seventies, a group of South African graduate students at Sussex University began applying Poulantzas' analytical device of "fractions of capital" to understanding the South African state. ${ }^{\mathrm{I}}$ "The work of the "Sussex School", as it became known, was widely read by South African leftists. Two features of the structuralist literature are worth noting. Firstly, while the Althusserians and Poulantzians put forward complex analyses of capital and the state, they had much less to say about working-class and popular movements. Where they did write about strikes and revolts, their analyses were often somewhat economistic and instrumental. Secondly, their writing was often characterized by stylistic obscurity. ${ }^{\text {IS }}$

For South African scholars who were uncomfortable with structuralism, Thompson's work offered an alternative. He provided a model of a sensitive and flexible way of thinking about the mass movements as they were actually emerging on the ground, and about their historical predecessors and antecedents. His demolition of Althusser and his cohorts, most famously in his Poverty of Theory, ${ }^{16}$ was an intellectual foundation for a new approach. And his clarity of style contrasted attractively with the turgidity of the Sussex School. Not all the History Workshop members took this pro-Thompson, anti-Althusser position; but it was to become the most influential one within the work of the group.

The South African university system changed during the late I 970 and early I 980 s, in a way that was favourable to new kinds of critical scholarship. There were three types of universities. First, the Afrikaans universities were all white, and firmly supportive of the apartheid project. Second, a series of segregated black universities had been set up by the government. Although they became hotbeds of student protest, they were largely dominated by pro-government Afrikaner professors and administrators. Finally, there were the so-called liberal universities, dominated by English-speaking whites, and this was where social history took root. In the late I970s, this latter group of universities began to increase their black enrollments. At Wits, black student numbers increased rapidly, from a handful

I 3. Harold Wolpe, "Capitalism and Cheap Labour Power in South Africa: From Segregation to Apartheid”, Economy and Society, I (1972), pp. 425-456.

I4. Robert Davies, David Kaplan, Mike Morris and Dan O’Meara, "Class Struggles and the Periodization of the State in South Africa”, Review of African Political Economy, 3 (1976), pp. $4-30$.

I 5. The work of Dan O'Meara is, however, a praiseworthy exception on both counts; see Dan O'Meara, Forty Lost Years: The Apartheid State and the Policy of the National Party 1948-1994 (Johannesburg, 1996).

16. E.P. Thompson, The Poverty of Theory (New York, 1978). 
at the end of the I970s to about a quarter of the student body at the start of the nineties. Moreover, this demographic change was concentrated in the humanities and social sciences, so that some classes in these disciplines were largely black by the end of the eighties. This shift brought a generation of students on to the campuses of Wits and the other universities who came out of high schools and townships where they had been involved in political mobilization and often in conflict with the army and the police. They had often been exposed to Marxist ideas, albeit usually in the formulaic version of the SACP. At the same time, white students at the liberal universities produced an increasingly leftist leadership in the National Union of South African Students (NUSAS). Campus life was characterized by a relentless political activism; confrontations with the police were common and tear gas often hung in the air. ${ }^{17}$ Yet, campuses were also somewhat protected environments. Their status as institutions and their international connections, the high level of media coverage of events there, even the strange deference of Afrikaner nationalists to the professoriate, meant that they were somewhat safer spaces than the streets of South Africa in general. In this context, critical scholars were able to bring their ideas to classrooms of exceptionally responsive students and to wider audiences. Thus, during the I980s and I990s a whole generation of undergraduate history and social science students at Wits, Natal, Cape Town, Rhodes, and Western Cape universities heard in at least some of their classes about Thompsonian ways of thinking about labour, culture, and politics. ${ }^{18}$ Some of these students went on to do graduate work and to publish work in a similar vein. Others, who did not go into academia, took some of the ideas into other spheres of cultural life.

What is striking about this conjuncture is that, because of the quasirevolutionary upheaval that South Africa was going through in the I980s, left intellectuals were, by and large, much less beset by doubts about Marxism than were their contemporaries in Europe and North America. In a sense, in South Africa, the I970s lasted until the early I990s, as far as the vigour of Marxist academic work was concerned.

\section{HISTORY WORKSHOP - ISSUES AND DEBATES}

A selection of papers from the first History Workshop conference in 1978 were rapidly edited by Belinda Bozzoli, the first History Workshop book coming out from Johannesburg's radical publisher, Ravan, in 1979. There was some representation of the more structuralist tendencies of the time in the volume, but Bozzoli's Thompsonian proclivities were already showing.

17. Glenn Moss, The New Radicals: A Generational Memoir of the I970s (Johannesburg, 2014). 18. The first four were the "liberal" universities. Western Cape was started as a segregated university for "Coloureds" (in South African racial terminology, people of "mixed" race) but successfully asserted its independence, claiming a role as the "university of the left". 
In her introduction to the book, she explained the purpose of the conference in this way:

Contributors were invited to present studies of the [Witwatersrand] region from the point of view of the "common man", the "people", the subordinate groups of society, be they factory workers, domestic servants, traders, diggers, the unemployed or the "marginal". In the tradition set by the Ruskin History Workshop this conference set out to begin the process of recreating Witwatersrand history from a grassroots perspective. ${ }^{19}$

It is worth noting here a certain vagueness about exactly how academics might be able to adopt the "point of view" of the oppressed. What is most striking, though, is the desire to apply the example and politics of the then current British style of social history in the South African context. There was a clear congruence between the way Bozzoli understood the Workshop's project and Thompson's critique of economistic, baseand-superstructure Marxism. Bozzoli wrote of the conference:

Time and again, it emerged in discussion that the economic identification of classes is not the last word, but merely the first, and that it is the political, social, cultural and ideological character of classes that renders them real and recognizable social categories. ${ }^{20}$

Bozzoli implicitly acknowledged the new history's debt to Thompson's famous re-definition of class. She pointed out that some of the papers in the book examined the processes whereby the black working class "makes itself, through its own action, the formation of alliances, the creation of cultural forms $[\ldots]]^{21}$

Bozzoli identified the lack of studies of the townships, the grim residential areas created by segregation and apartheid, as "the great unwritten history of the South African working class". ${ }^{22}$ Closing that gap has remained a central focus of Wits social historians up to the time of writing, especially in recent years through a programme of producing township local histories, based on oral history interviews, under the direction of Phil Bonner and Noor Nieftagodien. ${ }^{23}$

The conference also seems to have helped form an insight that would be very important to the work of the Wits History Workshop in subsequent years: In the I89os, Bozzoli observed, "[r]acial, skill and ethnic differences

19. Belinda Bozzoli, "Introduction: Popular History and the Witwatersrand", in idem (ed.), Labour, Townships and Protest (Johannesburg, 1979), p. 3 .

20. Bozzoli, "Popular History", p. 5.

21. Ibid.

22. Ibid.

23. Philip Bonner and Noor Nieftagodien, Alexandra: A History (Johannesburg, 2008); Noor Nieftagodien and Sally Gaulle, Orlando West (Johannesburg, 2012); Philip Bonner and Noor Nieftagodien, Ekurbuleni: The Making of an Urban Region. (Johannesburg, 2012). 
which divided those early workers from one another were not as rigidly institutionalized as they came to be". ${ }^{24}$ Previously, scholars had tended to project the very rigid racial boundaries characteristic of apartheid back into the South African past. What the research generated by the new thinking showed was that, in fact, nineteenth- and early twentieth-century South Africa's cities had been places where racial difference was often very blurred. It had subsequently taken an enormous amount of ideological and political work by those who held power to create the tightly policed racial divisions of apartheid South Africa. ${ }^{25}$ This view challenged not only the state's racial ideology, but also the essentialist arguments of some African nationalists.

Bozzoli shared Thompson's belief that working-class agency required a multi-layered and complex explanation, and that it could not be reduced to structural factors. With a jibe at the Althusserian concept of "overdetermination", she observed:

The mere existence of contradictions, however "overdetermined", is surely not a sufficient explanation for their expression in one or another kind of human action $[\ldots] \cdot{ }^{26}$

With views like that, Bozzoli was almost the ideal reader for Thompson's newly-published The Poverty of Theory. When, in 1983, Bozzoli produced a collection of papers from the second History Workshop conference, held at Wits two years earlier, she presented in her introduction a confident defence of the value of social history. The Poverty of Theory became something of an intellectual charter for Bozzoli's hostility to excessive theoreticism in general and to the influence of Althusser and Poulantzas on South African historiography in particular. Citing two contributions in the edited volume, one on the life of a western Transvaal sharecropper and one on Indian flower sellers in suburban Johannesburg, she commented that "[w]hen E.P. Thompson talks of class as 'experience' it would seem that these are two examples of what he meant", and went on to quote directly from Poverty of Theory: "experience [...] arises because men and women [...] are rational, and they think about what is happening to themselves and their world. ${ }^{27}$

24. Bozzoli, "Popular History", p. 7.

25. For an elaboration of this argument, see Eddie Koch, "Without Visible Means of Subsistence': Slumyard Culture in Johannesburg 191 8-1940", in Belinda Bozzoli (ed.), Town and Countryside in the Transvaal: Capitalist Penetration and Popular Response (Johannesburg, 1983), pp. I I-I75. Also see Charles van Onselen, New Babylon, New Nineveh: Everyday Life on the Witwatersrand I886-I9I4 (Johannesburg, 200I [1982]).

26. Bozzoli, "Popular History", p. i I.

27. Belinda Bozzoli, "Introduction: History, Experience and Culture", in idem (ed.), Town and Countryside, pp. I-47, is. 
The Thompsonian category of "experience" became perhaps the central idea in the South African social history writing of the 1980 s and beyond, in large part through Bozzoli's mediation. It was pervasively used, even by those who had not read much of Thompson. Its employment clearly marked the followers of social history as distinct from the structuralists.

Thompson's use of (a fairly unproblematized notion of) "rationality" would have struck a chord with leftist South African scholars for particular local reasons. Conservative, and even to some extent liberal, social scientists in the country had often portrayed African workers as driven by irrationalism; migrants came to the mines because of "the bright lights of the city" and so forth. For the new historians, part of their task seemed to be to insist that black workers acted as rationally as anyone else. Thus, Van Onselen's book on labour migrants in Zimbabwe, for example, is in part a passionate defence of the rationality of the miners. ${ }^{28}$ This way of thinking clearly glossed over the question of wherein "rationality" inheres. It tended to have the negative effect of leading to an avoidance of exploring the "irrational" (which, in any case, might again have its own rationality); workers' religious and magical beliefs, for instance, tended to be off-limits to the early Workshop historians. But this stance was not only understandable in the context of the time, it was also an important achievement, both intellectually and politically, in relation to prior views.

Bozzoli also followed Thompson in attacking "evolutionary and teleological narratives" of resistance. In doing so she was also taking a swipe at the practice of the South African left. She quoted Thompson's observation that "judgmental Marxism" tends to mathematically deduce from class analysis "the class consciousness which [the working class] ought to have (but seldom does have) if 'it' was properly aware of its own position and real interests". Basing herself on Thompson, Bozzoli condemned a politics that she saw as blaming the real political inadequacies of leaders on the supposed "failure" of the working class to develop the correct "consciousness". ${ }^{29}$ (She was probably here criticizing the whole range of more conventional Marxist political activists rather than any particular political faction).

In I983, Bozzoli published an influential article in the Journal of Southern African Studies advocating the need for a feminist turn in scholarship in South Africa. ${ }^{3 \circ}$ Interestingly, given Thompson's fraught relationship with feminism, Bozzoli's argument has clear links to Thompson's thought. She accused Wolpe and the structuralists of failing to recognize women's agency, because of their reliance on modes of arguments that were, ultimately, functionalist.

28. Charles van Onselen, Chibaro: African Mine Labour in Southern Rbodesia 1900-1933 (London, I980).

29. Bozzoli, "History, Experience", p. 34.

30. Belinda Bozzoli, "Marxism, Feminism and South African Studies", Journal of Southern African Studies, 9 (1983), I39-I7I. 
Bozzoli's position resonated closely with Thompson's idea that the mainstream American version of social science associated with Talcott Parsons, and Althusser's Marxism, were mirror images of each other. For Bozzoli, as for Thompson, both were accounts of society in which institutions operated in a machine-like fashion; they just reversed each other's political values. ${ }^{3 \mathrm{I}}$

In the last of her History Workshop edited volumes, based on the 1984 conference and appearing in 1987, Bozzoli sought, like Thompson, to nuance an understanding of class through an exploration of its relation to culture. ${ }^{32}$ She questioned simplistic versions of the concept of community. In the political discourse of the time, the term "community" was often used on the left, approvingly but unreflectively. Bozzoli wanted to point to the cleavages of gender, class and skill within communities that South African left politics tended to overlook.

There is no doubt that Bozzoli, through the introductions to her three edited books, set much of the direction of South African social history in general, and the Wits History Workshop in particular, and that that direction was a broadly Thompsonian one.

The work of Charles van Onselen represents perhaps the strongest substantive body of historical writing taking inspiration from Thompson in the South African scholarship. He made an extraordinary contribution to South African social history, following his early book on Zimbabwean labour history with a classic work on the early years of Johannesburg. ${ }^{33} \mathrm{His}$ magnum opus, published in the I990s, was an enormously elaborate biography of an African share-cropper, Kas Maine. In the book, Maine's life becomes a lens through which the whole history of rural South Africa during the Twentieth Century is read. ${ }^{34}$ Later, Van Onselen turned his attention to the Jewish gangsters and Irish bandits of early industrial South Africa. ${ }^{35} \mathrm{He}$ seldom explicitly invoked Thompson, but the Thompsonian stamp of his work was evident: in the desire to recover forgotten lives; the emphasis on the way in which pre-industrial obligations shape the working class; and in the stress on informal types of social resistance. ${ }^{36}$

3I. This assertion is based on comments by Bozzoli at a number of presentations that $\mathrm{I}$ attended during the I980s. For Thompson's argument see: Thompson, Poverty of Theory, pp. 75-8 I.

32. Belinda Bozzoli, "Class, Community and Ideology in the Evolution of South African Society", in idem (ed.), Class, Community and Conflict: South African Perspectives (Johannesburg, 1987), pp. I-43.

33. Van Onselen, Chibaro; Van Onselen, New Babylon.

34. Charles van Onselen, The Seed is Mine: The Life of Kas Maine, a South African Sharecropper (Cape Town, 1996).

35. Charles van Onselen, The Fox and the Flies: The World of Joseph Silver, Racketeer and Psychopath (London, 2007); Charles van Onselen, Masked Raiders: Irish Banditry in South Africa I880-I899 (Cape Town, Zebra, 2010).

36. Also see the following assessments: Martin J. Murray, "The Triumph of Marxist Approaches in South African Social and Labour History", Journal of Asian and African Studies, 23 (1988), 
A distinguished American Africanist, Luise White, describes Van Onselen's book on Johannesburg as "pure Thompson" and the author as being "far and away the most Thompsonian" of the South African scholars. ${ }^{37}$

The American scholar Martin Murray took Van Onselen to task for not emulating Thompson, as he did not tell a tale of the formation of a working class. ${ }^{38}$ And indeed, Van Onselen has certainly been attracted to the study of those who resisted the process of proletarianization in individualistic ways; the share-croppers, the self-employed and the criminals. But this focus does resonate with Thompson's concern for the casualties of industrialization. And it could be argued that it is a virtue of Van Onselen's work that he ultimately does not yield to a teleology of class formation.

If I have concentrated here on the work of Bozzoli and van Onselen it is not because they were necessarily the most "typical" of the History Workshop scholars. Indeed, their intellectual and political trajectories were somewhat unusual ones. Most of the I970s and I 980 s generation of social historians have maintained political positions of critical support towards the trade unions or the ANC or socialist groupings, or at least have continued to occupy a kind of post-Marxist leftist position. By contrast, Van Onselen came at an early stage to a position of hostility to the ANC, which he saw as mindlessly nationalist, and to the organized left in general. Bozzoli, equally critical of the ANC, has recently become a member of parliament for the broadly liberal Democratic Alliance. However, the focus of this article is less the History Workshop itself than Thompson's influence, and in this regard their work is the most significant. Nobody made a more systematic attempt than Bozzoli to draw out the implications of Thompson's ideas for the South African context, and nobody made a more notable and influential attempt to apply those ideas than Van Onselen.

\section{A BROADER THOMPSONIAN IMPACT}

The influence of Thompson has, however, diffused much more widely through South African historical writing. Dunbar Moodie deployed the notion of "moral economy" to brilliant effect in analyzing the 1946 Witwatersrand African mineworkers strike on the basis of his interviews with elderly participants. ${ }^{39}$ History Workshop member Peter Delius and Oxford historian Stanley Trapido also invoked "moral economy" in their

pp. 79-101, 86; Fredrick Cooper, “Work, Class and Empire: An African Historian's Retrospective on E.P. Thompson", Social History, 20 (1995), pp. 235-24I, 237.

37. Luise White, personal email communication to the author, 25 August 2013.

38. Murray, “Triumph", p. 92.

39. T. Dunbar Moodie, “The Moral Economy of the Black Miner’s Strike of I946”, Journal of Southern African Studies, I3 (1986), pp. I-35. 
work on rural social relations in the Transvaal. ${ }^{4}$ Paul La Hausse acknowledged Thompson's part in the "specifically English debates about culture and history", which shaped the finely researched series of studies of African working class history and culture in Durban that he produced. ${ }^{4 \mathrm{I}}$ Bill Nasson, as a young South African student in England in the I970s, attended a Thompson lecture at Hull, and was also present when, as he recalls, Thompson "shredded" his critic Richard Johnson at Oxford. ${ }^{42}$ Nasson acknowledges the influence on Thompson's thinking, especially concerning liberties and the rule of law, on his influential book about men of colour in the Cape who fought for the British in the Boer War. ${ }^{43}$ Durbanbased American Bill Freund, who became a major historian of the African city, got to know Thompson personally while living in England, and was deeply impressed by him. ${ }^{44}$ And numerous graduate students were influenced by Thompson in the remarkably high quality graduate thesis work produced under Bonner and Delius's supervision at Wits in the I980s.

There was a danger, though, that the dominance of the local version of Thompson amongst the social historians could lead to a closure of theoretical discussion. ${ }^{45}$ It is true that, under Phil Bonner's leadership after 1987, the History Workshop were building increasingly sophisticated understandings of urbanization, of generation, and of rural and urban political cultures. But right into the early 1990s, there was relatively little interest amongst South African social historians in engaging with the proliferating new international debates on post-structuralism and post-colonialism. A striking contrast is with the Indian Subaltern Studies school, which emerged in that period out of a not dissimilar social history group, but which attained a huge international impact through addressing major theoretical debates and by advancing novel approaches. History Workshop did not have an interest in engaging with theory in this way. Their dominant mode of research was strongly empirical. And there was a tendency to see current developments in theory as a modish distraction from politics. There was also an element of parochialism: South Africans were overwhelmingly preoccupied with their national situation and, in the

40. Peter Delius and Stanley Trapido, "Inboekselings and Oorlams: The Creation of a Servile Class", in Bozzoli (ed.), Town and Countryside, pp. 53-88.

4I. Paul La Hausse, "Note", in Paul Maylam and Iain Edwards (eds), The People's City: African Life in Twentieth-Century Durban (Plymouth, NH/Pietermaritzburg, I996), pp. 32-33, 32.

42. Bill Nasson, personal email communication to the author, I 2 August 2013.

43. Bill Nasson, Abraham Esau's War: A Black South African War in the Cape 1899-1902 (Cambridge, I99I).

44. Bill Freund, contribution to a non-public Gmail forum on Thompson, 20I3. I would like to thank Professor Keith Breckenridge for organizing this forum and permitting me to draw on the contributions.

45. See the critical remarks by Deborah Posel, "Social History and the Wits History Workshop", African Studies, 69 (2010), pp. 29-40, 34. 
eighties, were academically isolated, internationally, by the cultural boycott of South Africa.

The idea of popularizing historical research in a context of political and social struggles of course predated the work of E.P. Thompson. In the UK there was a long history of such work, by both Labour Party and Communist historians and activists. Thompson was not therefore the direct inspiration for the History Workshop's initiatives in popularizing historical research. Nevertheless, there was at least an elective affinity between the work of History Workshop in this field and the ideas of E.P. Thompson, the sometime Workers' Education Association tutor. In I98 I, Luli Callinicos produced a book, Gold and Workers, aimed at bringing the new research on the history of South African industrialization to a working-class audience. ${ }^{46}$ This book was extremely successful in its aims. It was widely used in trade union educationals in the I980s, and was serialized in the newspaper of the powerful new National Union of Mineworkers. Explaining her intentions, Callinicos cited Thompson, in suggesting that "historical consciousness" might help us to realize the "possibilities of transformation". ${ }^{47}$ It is noteworthy that the book includes a brief section drawing explicit parallels between industrialization in South Africa and the Industrial Revolution in England. Callinicos used this comparison in an attempt to show how the racial attitudes of upper-class whites in contemporary South Africa worked in a similar way to the contempt of the nineteenth-century English bourgeoisie for the working class. This kind of parallelism, which would certainly be rejected by later post-colonial theorists, was quite appealing to South African social historians. Though they had seen too much of the problems of postcolonial Africa to entirely share Thompson's early i960s confidence that "[c]auses which were lost in England might, in Asia or Africa, yet be won" ${ }^{8}$ they certainly saw the processes of industrialization and urbanization in eighteenth-century England and twentieth-century South Africa as alike in crucial ways.

If Scott Hamilton is correct to say that one of Thompson's core ideas was "the essential unity of political, scholarly and imaginative work", then History Workshop certainly laboured in that spirit. ${ }^{49}$ Well-attended public cultural festivals, drawing in trade unionists, students, community activists, and students, accompanied all the History Workshop conferences during the first decade and a half. At these events there were numerous

46. Luli Callinicos, Gold and Workers: A People's History of South Africa, vol. I (Johannesburg, 1985 [198I]).

47. Luli Callinicos, "The People's Past: Toward Transforming the Present", in Bozzoli (ed.), Class, Community and Conflict, pp. 44-64, 64 .

48. Thompson, The Making, p. I3.

49. Scott Hamilton, The Crisis of Theory: E.P. Thompson, the New Left and Postwar British Politics (Manchester, 20I I), p. 40. 
performances by workers' choirs, dance and drama groups, concerts and exhibitions by sympathetic musicians and artists, screenings of political films, and public lectures by scholars. For the first conference this "public day" was held on a small scale in the industrial town of Benoni. The festivals subsequently were moved to the Wits campus and steadily grew in size. In I984 about 3,500 people attended the event, and in 1987 5,000, a large proportion of them in both years trade unionists. ${ }^{50}$ At the 1990 conference, held shortly after the government had unbanned the liberation movements, a roaring University Great Hall greeted a rousing speech by Ahmed Kathrada, an ANC leader recently freed after a quarter of a century's imprisonment on Robben Island. ${ }^{\text {I }}$

With the transition to democracy, the opening of many other political spaces meant that there was no longer an audience for this type of jamboree. Thus, when the workshop held a conference on the concept of Democracy in 1994, the academic event was a great success, attracting scholars from many African countries, Europe, and North America. But the cultural festival was a flop. Phil Bonner astutely turned the workshop towards new modes of public history, appropriate to the new times. Perhaps his most notable achievement in this sphere was the creation of Johannesburg's Apartheid Museum, which has become a landmark for visitors to the city, and which presents a distinctly History-Workshop-inflected account of South African history. The narrative focuses - some might say disproportionately - on the black working-class on the Rand, looking at daily life and culture, as well as repression and political movements. The core of the overview of South African history presented in the museum is conceived in a recognizably Thompsonian manner. And this approach is not surprising - most of the text panels in the exhibition were written by History Workshop-linked academics.

Around the time of the transition to democracy in 1994, however, the tides of opinion amongst the South African radical intelligentsia turned strongly against Thompsonian social historians. One issue was the

50. Philip Bonner, "Keynote Address to the 'Life after Thirty' Colloquium”, African Studies, 69 (2010), pp. I $3-27$.

5I. Through the I980s, the History Workshop and other political intellectuals were sometimes criticized by the exile ANC for acting independently of its political leadership. At the same time, left academics' connections to the United Democratic Front (UDF) (which was aligned to the ANC, but rather more democratic and inclusive in practice), student political groups, and unions were dense, varied and generally more cordial. Though groups did criticize History Workshop for not including them in the more academic side of its activities, they were willing to have a relationship with it. History Workshop's collaboration with the UDF-aligned newspaper, New Nation, and with the FOSATU unions are good examples of this. Many observers now see the "internal" opposition movements as having been more democratic than the exile ANC and trace many problematic aspects of contemporary South African politics to the triumph of the exile faction. See Seekings, The UDF. 
rhinoceros in the room: race. The History Workshop committee was mainly white. The proportion of black paper presenters in History Workshop conferences steadily increased, but still constituted a minority. Perhaps surprisingly, these problems had not really been a subject of conflict in the previous decade (at least, not of publicly visible conflict). The oppositional public culture of the time tended to deflect attention away from such issues. In the I980s, at Wits and the other universities, there had been remarkable unity between left academics and students, who had, on occasion, faced off against police together in campus demonstrations. Both FOSATU and the UDF organizations had a strong commitment to playing down potential racial divisions amongst the anti-apartheid forces. But the I990s saw a change in these political dynamics. Black students became increasingly confrontational towards university authorities over racially defined issues, in ways which were often resented by even leftish professors. And a more overtly African nationalist position began to be articulated by sectors of the ANC, which was to become especially strong under the presidency of Thabo Mbeki. In this context, the Workshop was bound to be criticized for its racial make up, and it was. More generally, white social historians came under scrutiny for the racial politics of their professional practice. Some critics particularly questioned the employment by white social historians of black research assistants, arguing that the assistants had been exploited or given inadequate credit for their intellectual contributions. The lack of proficiency in African languages of most white social historians was deplored. It was also claimed, especially by activists from a Black Consciousness background, that the social historians' analytical emphasis on class was a way of avoiding the question of race.

The Workshop did change its racial composition, gradually, and then quite dramatically after Phil Bonner gained funding for a large group of black graduate students in the mid 2000s. But the racial relationships under which some of the classic Wits Social History work was produced have continued to be used by critics to cast doubt over its validity.

Overlapping with the racial issue was the increasing challenge to a Thompsonian social history from scholars influenced by poststructuralist and postcolonial theory. This was perhaps most forcefully articulated, from the late I990s, by Ciraj Rassool and others from the University of the Western Cape. ${ }^{22}$ These scholars argued that the South African social historians had been blind to issues of representation and institutional power in their academic practice. Social historians were accused of presuming to speak for the working class. The History Workshop was criticized for

52. Ciraj Rassool, "Power, Knowledge and the Politics of Public Pasts", African Studies, 69 (2010), pp. 79-100. Also see the earlier intervention: Leslie Witz, Gary Minkely and Ciraj Rassool, "Who speaks for South African pasts?", unpublished paper presented at the Conference of the South African Historical Society, University of the Western Cape, 1999. 
treating workers simply as an audience and not as interlocutors. The social history literature was portrayed as mindlessly empiricist and its authors as crassly averse to theoretical engagement. It was suggested that the apparently impressive achievements of South African social historians using oral history interviews were fundamentally flawed, because they had naively treated interviews as sources of evidence about the past, when they should have heard them as statements about the present. At their most extreme, these positions tended to suggest that it was only possible to work with representations of history, and that it was therefore quite impossible to say anything substantive about the past. This latter point resonated in a striking way with the development of a post-apartheid heritage industry. In the transitional years after 1994, considerable resources, from both the state and the private sector, became available for commemoration and memorialization of past political struggles and many historians and history graduates became involved in the resulting initiatives. Unsurprisingly, these critics of social history had no interest in engaging Thompson's work. For them, it was hopelessly tainted by its History Workshop associations.

Practitioners of the Thompson-derived brand of social history were not deaf to criticisms based either on racial politics or on theoretical grounds. Phil Bonner acknowledged a degree of validity in some of them in his keynote speech at the History Workshop's thirtieth anniversary conference in 2009. ${ }^{53}$ But the question really was whether to view the work of the Thompsonian social historians as flawed but valuable, or whether, as Rassool and his supporters seemed to think, it needed to be totally abandoned. Yet surely, as Geoff Eley has argued for the British and American social history of the I970s, it should be possible to recognize the limitations of a body of historical work, while still valuing what was creative and innovative about it. ${ }^{54}$

However, scholars who had come up through the activities of the social history movement did continue to keep some direct interest in Thompson alive. For instance, Thompson continues to figure prominently in teaching, as anecdotal information indicates: I taught Thompson's essay on time to hundreds of Wits undergraduate Sociology students during the r99os. Keith Breckenridge taught the chapter on Methodism of The Making to students at the University of Kwazulu Natal in the same period. Peter Alexander included the "class" section of The Making in his courses at the University of Johannesburg over many years. ${ }^{55}$ Bill Nasson currently teaches The Making to students at the University of Stellenbosch. ${ }^{56}$

53. Bonner, "Keynote".

54. Geoff Eley, A Crooked Line: From Cultural History to the History of Society (Ann Arbor, 2005).

55. Keith Breckenridge and Peter Alexander, contributions to closed Gmail forum on Thompson, 2013.

56. Bill Nasson, personal email communication to the author, I2 August $20{ }_{3} 3$. 
This brings me back to Jacob Dlamini's book. If some South African academics have hurled Thompson out of the front door, he may have returned through the back, via the work of a younger generation of writers in non-academic genres. The literary scholar Hedley Twidle has recently suggested that the remarkable current boom in South African non-fiction writing has an affinity as a genre with the strong social history tradition. ${ }^{57}$ I agree with him, but I would suggest that the connection is even more direct than he recognizes. The current generation of non-fiction writers were often influenced by, and drew on, the teaching and writing of the social historians. Dlamini was a student in the Wits history department and acknowledges its influence on his intellectual formation, which certainly helps explain his reference to Thompson. ${ }^{8}$ In opposing his own investigations of real diversity of black working-class experience to an official political narrative focused on repression and resistance, Dlamini was certainly proceeding in a thoroughly Thompsonian manner. And in his evocation of "reciprocity and mutual obligation" in township life, there is surely a sensibility at work that Thompson's admirers would find sympathetic. There are other examples of this direct connection of the new South African non-fiction and social history: Xolela Mangcu, a foremost public intellectual and journalist, and author of a recent biography of Steve Biko, ${ }^{59}$ sees Thompson's ideas as a useful starting point for thinking about Biko's context in the history of the Eastern Cape. He says his reading in social history has given him "a better sense of the sub-political currents in our society". And he comments that "Thompson's use of 'precedent' always appealed to me - e.g. how Thomas Paine's work set the contours for Radicalism in Britain a hundred years later". 60 The leading non-fiction writer Jonny Steinberg, a Wits student at the height of the social history wave, cites a number of social historians in his non-fiction works on contemporary South Africa. In his award-winning book about crime and imprisonment, The Number, Steinberg draws heavily on Van Onselen's work on the history of prison gangs. ${ }^{6 \mathrm{I}}$ It does indeed seem that the intellectual and cultural influence of South African social history has diffused far beyond the boundaries of its own academic genre.

It can be speculated that one reason for this is that the mode of writing of the social historians provided non-fiction writers with usable literary models. An accessible, story-telling style was one of the features of the

57. Hedley Twidle, “'In a Country where you couldn't make this Shit up'? Literary Non-Fiction in South Africa", Safundi: The Journal of South African and American Studies, I 3 (2012), pp. 5-28. 58. Jacob Dlamini, Unpublished Keynote address at South African Historical Society Conference, Durban, July 20 I I.

59. Xolela Mangcu, Biko: A Biography (Cape Town, 2012).

60. Xolela Mangcu, personal email communication to the author, 4 July 2013.

6r. Jonny Steinberg, The Number (Johannesburg, 2004). 
South African social historians. This came out of both the stylistic influence of authors like Thompson and Hobsbawm, and the desire to communicate with a non-academic audience. Many of the History Workshop contributors honed their popular writing skills on a long series of historical articles produced by the group for the UDF-aligned paper, the New Nation, in the I980s. Van Onselen, Tim Couzens, Bill Nasson and Peter Delius are all exemplary writers in a "plain English", Thompsonian manner. Of course, post-structuralists would claim that their apparent clarity is a discursive snare and a delusion. But it remains evident that the convoluted modes of poststructuralist self-expression were not transferable into writing intended for a popular audience, whereas those of the social historians were.

What, then, can be said of the future of Thompsonian thought in South Africa? For this, the state of the nation needs to be considered briefly. Nobody in their right mind would contest that South Africa is an infinitely better country than it was in the I970s: the great crime of formalized racial oppression is gone for good. And yet, contemporary South Africa is a profoundly disillusioning place, marked by mass unemployment, political corruption, continued (although no longer exclusively racially defined) economic inequality, crime, and violent clashes between police and protestors.

What relevance might a local Thompsonian tradition have in these grim circumstances? I want to answer this question in a provocative way, by suggesting that the South African social historians were and are romantics. This is certainly a label most of them would hate, for they tend to see themselves as drawing on social science and as hard-headed and realistic in their political judgements. But for Thompson, romanticism was not a pejorative term; indeed, it marked a quality of mind essential to the practice both of social change and of radical history. Writing of his hero, William Morris, in 1976, Thompson suggested that what had often been seen as romantic failure in Morris was actually a positive alternative to the scientism that the left was to develop. Morris's romanticism contrasted with mainstream Marxism's “lack of a moral self-consciousness or even a vocabulary of desire, its inability to project any images of the future, or even its tendency to fall upon the Utilitarians' earthly paradise - the maximization of economic growth" ${ }^{62}$ For Thompson, moral concern and utopianism were crucial values. For all its many undoubted deficiencies and inconsistencies, South African social history has had such profound moral and future-orientated purposes. It has sought to give the people of the past the respect they deserved, and in doing so to help imagine a different future

62. E.P. Thompson, "Postscript: 1976", in Dorothy Thompson (ed.), The Essential E.P. Thompson (New York, 200I), p. 254. 
South Africa. Thompson approvingly quoted Morris: "I have heard people miscalled for being romantic, but what romance means is the capacity for a true conception of history, a power of making the past part of the present". ${ }^{63}$ We may now smile at the idea of a "true" conception of history, but if the social history tradition endures in South Africa, it may be because it provides just such a way of telling stories about the past which make that vital connection to the present. If South African needs anything now, it is moral dissent and a "utopian" envisaging of something different. It is up to a younger generation of South African intellectuals to see whether they can find any resources in the local legacy of E.P. Thompson that could help them in that struggle. Strangely enough, there are signs that they just might do so.

\author{
TRANSLATED ABSTRACTS \\ FRENCH - GERMAN - SPANISH
}

Jonathan Hyslop. E.P. Thompson en Afrique du Sud: la pratique et la politique de l'histoire sociale dans une ère de révolte et de transition, I976-20I2.

L'œuvre d'E.P. Thompson eut un impact gigantesque sur la rédaction de l'histoire en Afrique du Sud depuis les années 1970. Cet article retrace la montée de cette tendance historiographique, en se concentrant particulièrement sur l'Atelier d'histoire de de l'Université du Witwatersrand à Johannesburg (Wits History Workshop). Il met en relief la manière dont une version sud-africaine de la pratique historique thompsonienne fut théorétisée, et il décrit certaines utilisations des idées de Thompson par les historiens sud-africains. L'article montre comment l'Atelier de l'histoire tenta de populariser sa recherche, et il examine les projets politiques sous-tendant ces activités. Enfin, l'article suggère que bien que l'influence des historiens de l'histoire sociale sud-africains de tendance thompsonnienne ait décliné, leur œuvre eut sur la culture littéraire de l'Afrique du Sud une influence durable qui alla bien au-delà du monde universitaire.

Traduction: Christine Plard

Jonathan Hyslop. E. P. Thompson in Südafrika: Praxis und Politik der Sozialgeschichte in einem Zeitalter der Revolte und des Übergangs, I976-20I2.

E.P. Thompsons Arbeiten haben seit den I970er Jahren einen enormen Einfluss auf die südafrikanische Geschichtsschreibung ausgeübt. Der Beitrag rekonstruiert die Genese dieser historiografischen Strömung und konzentriert sich dabei insbesondere auf die Geschichtswerkstatt an der Witwatersrand University in Johannesburg 
(Wits History Workshop). Er umreißt, wie eine südafrikanische Version von Thompsons historiografischer Praxis theoretisiert wurde und skizziert einige der Formen, in denen Thompsons Ideen von südafrikanischen Historikern umgesetzt wurden. Der Beitrag schildert, wie die Geschichtswerkstatt diese Arbeiten zu popularisieren versuchte und untersucht die damit verbundenen politischen Projekte. Wie der Beitrag schließlich zeigt, hat der Einfluss von an Thompson orientierten südafrikanischen Sozialhistorikern zwar abgenommen, deren Arbeiten aber dennoch einen bleibenden Einfluss auf die literarische Kultur des Landes ausgeübt haben, auch weit über den Wissenschaftsbetrieb hinaus.

Übersetzung: Max Henninger

Jonathan Hyslop. E.P. Thompson en Sudáfrica: la práctica y la política de la historia social en una era de revuelta y transición, I976-20I2.

La obra de E.P. Thompson ha tenido un enorme impacto en la escritura de la historia en Sudáfrica desde la década de i970. En este artículo recorremos el surgir de esta corriente historiográfica, centrándonos especialmente en el Taller de Historia de la Universidad de Witwatersrand en Johanesburgo (Wits History Workshop). En el texto se considera cómo se teorizó una versión propia sudafricana de la práctica histórica thompsoniana, y esboza alguna de las formas en que fueron utilizadas las ideas de Thompson entre los historiadores sudafricanos. En el artículo se observa cómo el Taller de Historia intentó popularizar sus trabajos de investigación y analiza los proyectos políticos que se encuentran tras estas actividades. Por último, el texto sugiere que aunque la influencia estilo-thompsoniano en los historiadores sociales sudafricanos ha ido en declive, su obra, más allá del ámbito académico, sí ha tenido un impacto duradero en la cultura literaria del país.

Traduccíon: Vicent Sanz Rozalén 